\title{
Correction to: How does crop insurance influence pesticide use? Evidence from French farms
}

\author{
Geoffroy Enjolras ${ }^{1} \cdot$ Magali Aubert $^{2}$ \\ Published online: 17 December 2020 \\ (C) The Author(s) 2020
}

\section{Correction to: Review of Agricultural, Food and Environmental Studies. https://doi.org/10.1007/s41130-020-00129-5}

The article "How Does Crop Insurance Influence Pesticide Use? Evidence from French Farms", written by Geoffroy Enjolras and Magali Aubert, was originally published electronically on the publisher's Internet portal on 9 November 2020 without open access. With the authors' decision to opt for Open Choice the copyright of the article changed on 21 October 2020 to "C) The Author(s) 2020" and the article is forthwith distributed under a Creative Commons Attribution.

This article is licensed under a Creative Commons Attribution 4.0 International License, which permits use, sharing, adaptation, distribution, and reproduction in any medium or format, as long as you give appropriate credit to the original author(s) and the source, provide a link to the Creative Commons license, and indicate if changes were made. The images or other third party material in this article are included in the article's Creative Commons license, unless indicated otherwise in a credit line to the material. If material is not included in the article's Creative Commons license and your intended use is not permitted by

The online version of the original article can be found at https://doi.org/10.1007/s41130-020-00129-5

Geoffroy Enjolras

geoffroy.enjolras@grenoble-iae.fr

Magali Aubert

magali.aubert@inrae.fr

1 University Grenoble Alpes, Grenoble INP, CERAG EA 7521, Domaine Universitaire, 38000 Grenoble, France

2 MOISA, Univ Montpellier, CIRAD, CIHEAM-IAMM, INRAE, Institut Agro, Montpellier, France, 2 place Viala, 34060 Montpellier Cedex 2, France 
statutory regulation or exceeds the permitted use, you will need to obtain permission directly from the copyright holder. To view a copy of this license,, visit http://creativecommons.org/licenses/by/4.0/.

Publisher's note Springer Nature remains neutral with regard to jurisdictional claims in published maps and institutional affiliations. 